\title{
The role of Azadinium spinosum (Dinophyceae) in the production of azaspiracid shellfish poisoning in mussels
}

\author{
Rafael Salas ${ }^{a, *}$, Urban Tillmann ${ }^{b}$, Uwe John ${ }^{b}$, Jane Kilcoyne ${ }^{a}$, Amanda Burson ${ }^{a}$, Caoimhe Cantwell ${ }^{a}$, \\ Philipp Hess ${ }^{c}$, Thierry Jauffrais ${ }^{c}$, Joe Silke ${ }^{a}$
}

\author{
a Marine Institute, Rinville, Oranmore, Co. Galway, Ireland \\ b Alfred Wegener Institute for Polar and Marine Research, Am Handelshafen 12, D-27570 Bremerhaven, \\ Germany \\ ${ }^{c}$ Institut Français de Recherche pour l'Exploitation de la mer (IFREMER), rue de l'lle d'Yeu, B.P. 2110544311 , \\ Nantes, Cedex 03, France \\ *: Corresponding author : Rafael Salas, Tel.: +35391387241; fax: +35391387238 ; \\ email address : $\underline{\text { Rafael.salas@marine.ie }}$
}

\begin{abstract}
:
Azaspiracids (AZAs) are a group of lipophilic polyether compounds first detected in Ireland which have been implicated in shellfish poisoning incidents around Europe. These toxins regularly effect shellfish mariculture operations including protracted closures of shellfish harvesting areas for human consumption. The armoured dinoflagellate Azadinium spinosum Elbrächter et Tillmann gen. et sp. nov. (Dinophyceae) has been described as the de novo azaspiracid toxin producer; nonetheless the link between this organism and AZA toxin accumulation in shellfish has not yet been established. In August 2009, shellfish samples of blue mussel (Mytilus edulis) from the Southwest of Ireland were analysed using liquid chromatography-tandem-mass spectrometry (LC-MS/MS) and were found to be above the regulatory limit $\left(0.16 \mathrm{\mu g} \mathrm{g}^{-1}\right.$ AZA-equiv.) for AZAs. Water samples from this area were collected and one algal isolate was identified as $A$. spinosum and was shown to produce azaspiracid toxins. This is the first strain of $A$. spinosum isolated from Irish waters. The Irish $A$. spinosum is identical with the other two available A. spinosum strains from Scotland (3D9) and from Denmark (UTHE2) in its sequence of the D1-D2 regions of the LSU rDNA.
\end{abstract}

A $24 \mathrm{~h}$ feeding trial of blue mussels ( $M$. edulis) using an algal suspension of the Irish $A$. spinosum culture at different cell densities demonstrated that $A$. spinosum is filtered, consumed and digested directly by mussels. Also, LC-MS/MS analysis had shown that AZAs were accumulating in the shellfish hepatopancreas. The toxins AZA1 and -2 were detected in the shellfish together with the AZA analogues AZA3, AZA6, AZA17 and -19 suggesting that AZA1 and -2 are metabolised in the shellfish within the first $24 \mathrm{~h}$ after ingestion of the algae. The levels of AZA17 detected in the shellfish hepatopancreas (HP) were equivalent to the levels of AZA1 but in the remainder tissues the levels of AZA17 were four to five times higher than that of AZA1, only small quantities of AZA3 and -19 were present with negligible amounts of AZA6 detected after the $24 \mathrm{~h}$ period. This could have implications in the future monitoring of these toxins given that at present according to EU legislation only AZA1-AZA3 is regulated for. This is the first report of blue mussels' ( $M$. edulis) feeding on the azaspiracid producing algae $A$. spinosum from Irish waters. 


\section{Highlights}

- Confirmation of Azadinium spinosum from Ireland as the producer of azaspiracid toxins. - A $24 \mathrm{~h}$ feeding experiment confirms that mussels (Mytilus edulis) are able to ingest $A$. spinosum cells directly without the need of vector species. - AZA toxins can accumulate in mussels above the regulatory level within $24 \mathrm{~h}$. - There is a rapid conversion of AZA-1 to AZA-17 and AZA-2 to AZA-19 in the mussels' tissue within $24 \mathrm{~h}$. The ratio of $A Z A-17$ to $A Z A-1$ is $5: 1$ in the mussels' remainder tissue.

Keywords: Azaspiracids ; AZP ; AZA toxins ; Biodeposits ; Dinoflagellates ; Feeding experiment ; Ireland ; LC-MS/MS ; Mussels ; Phylogeny ; Taxonomy

\section{Introduction}

Azaspiracids (AZAs) are a group of lipophilic polyether toxins which were first detected in shellfish in 1995 from a contaminated batch of mussels (Mytilus edulis) from Killary harbour, county Galway on the west coast of Ireland. This event led to a poisoning incident in the Netherlands in November of that year where eight people became ill with symptoms typical of diarrhetic shellfish poisoning (DSP), however chemistry results showed that DSP toxins 
51

were only found in the shellfish at low concentrations and phytoplankton samples did not show the presence of DSP toxin producing algae in the water, yet the mousse bioassay was strongly positive (McMahon \& Silke, 1996). In 1998 this novel group of compounds were isolated and chemically characterized from shellfish (Satake et al., 1998, Ofuji et al.1999). A few years later azaspiracids were confirmed in the UK and Norway (James et al., 2002), Morocco (Taleb et al., 2006) and Portugal (Vale et al., 2008) suggesting that azaspiracid toxicity had a more extensive distribution along the west European Atlantic seaboard and as far as north Africa . There is evidence now that the distribution of azaspiracids may be worldwide with azaspiracids found in Japan (Ueoka et al., 2009), Chile (Alvarez et al. 2010, Lopez-Rivera et al. 2010) and Canada (Twiner et al.,2010) .

The development of routine chemical analysis as a monitoring tool showed azaspiracid concentrations found in M.edulis in Ireland between 2003 and 2010 using LC-MS/MS (Fig. 1) indicates that the presence of azaspiracids has been a recurring problem since 2005 annually. However, AZA toxins were found at concentrations below the regulatory limit in 2003 and not detected in 2004 and the first half of 2005, suggesting that there could be a cyclical element to AZA events. While the accumulation of AZA toxins has been reported in a number of different shellfish species (Table 1), levels above the regulatory limit have only been observed in blue mussels (Mytilus edulis) and pacific oysters (Crasostrea gigas) in Ireland.

Due to the ability to accumulate high levels of AZA toxins, mussels have become an important source of AZAs for toxin isolation (Furey et al., 2003, Perez et al., 2010). Since the first characterization of AZA1 by Satake et al., 1998 other structural variants have been isolated and characterised: AZA2 and AZA3 (Ofuji et al., 1999a: 2001) and AZA6-AZA11 (James et al., 2003a) with AZA12 theoretically postulated, the number of variants was 
increased from AZA12-AZA 32 later by Rehmann et al., 2008 with the discovery of new dihydroxy and carboxy-AZAs. Most of these AZA variants have been reported to be shellfish metabolites (Rehman et al., 2008) rather than de novo products of plankton, apart from AZA1, AZA2 and AZA3 (Furey et al, 2003). However, Krock et al., 2009 only detected AZA1 and AZA2 in the field samples from Scotland generating uncertainties over the production of AZA3 by plankton. Fux et al., 2009 did find low amounts of AZA3 using Solid Phase Adsorption Toxin Tracker Device (SPATT), a passive sampler, but concluded that a heat treatment step could have influenced the enzymatic activity of the SPATT prior to the extraction allowing the metabolism of AZA1 to AZA3.

In 2008, the causative organism was discovered from the North-East coast of Scotland (Krock et al., 2009) and described as a genera and species novo (Tillman et al., 2009). This organism, a small armoured dinoflagellate named A. spinosum was shown to produce AZA toxins in culture and effectively identified as de novo producer of azaspiracids. Later, McCarron et al., 2009 reported that AZA17 and -19 are formed by oxidation of the 22-methyl group of AZA1 and -2 respectively. In this study, heat induced decarboxylation of AZA17 and -19 from AZA3 and - 6 was demonstrated showing the possible bioconversion pathways of these toxins in shellfish.

The Marine Institute phytoplankton unit collected water samples between August and September of 2009 following positive results in blue mussels of AZA toxins. The samples yielded several isolates and cultures, one of which was shown to produce AZA1 and AZA2. The Irish isolate was provisionally named SM2. Here, we report on the taxonomic identity of the Irish toxin producer and the genotypic/phenotypic relationship with other Azadinium species and its toxin profile. The link between A.spinosum toxicity and toxin accumulation in shellfish had not yet been established. It was not known whether blue mussels were able to 


\subsubsection{Isolation and culture conditions}

The dinoflagellates were isolated using single cell isolation by micropipette in 96 cell tissue

directly ingest the small thecate dinoflagellate A. spinosum or if toxin accumulation in mussels is mainly achieved via planktonic vector species which have potentially accumulated AZA toxins by consuming the small armoured dinoflagellate. Thus, a feeding trial was designed to demonstrate that blue mussels are able to feed and digest directly from an algal suspension of A.spinosum, that AZA toxins accumulate in their digestive system and that ultimately these are metabolised into other AZA analogues.

\section{Materials and Methods}

2.1 Sample collection, isolation and culture of an AZA producing dinoflagellate

\subsubsection{Field collection using a submersible pump}

The culture of an Irish strain of A. spinosum provisionally designated as SM2 was established from water samples collected in the South west coast of Ireland, at Gearhies pier, Bantry bay (latitude: $51^{\circ} 39^{\prime} 4.7^{\prime}, \mathrm{N}$, longitude: $9^{\circ} 35^{\prime} 11^{\prime \prime}$ E) during September of 2009 coinciding with an increase of AZA toxin in shellfish as reported by the Marine Institute biotoxin monitoring programme. The water samples were collected using a pump below surface and at $3 \mathrm{~m}$ depth, approximately $100 \mathrm{~L}$ of seawater were pumped into a fraction sampler to separate and concentrate the different size fractions $(60 \mu \mathrm{m}, 38 \mu \mathrm{m}$ and $20 \mu \mathrm{m})$. The filtrate was also collected into $25 \mathrm{~L}$ polyethylene drums for cell concentration down to $3 \mu \mathrm{m}$ in size using a vacuum pump at low pressure and $3 \mu \mathrm{m}$ pore size TSTP Millipore ${ }^{\mathrm{TM}}$ membrane filters. Approximately $5 \mathrm{~L}$ of $20 \mu \mathrm{m}$ sample filtrate was concentrated down $(3 \mu \mathrm{m})$ to approximately $50 \mathrm{ml}$ volume before isolation. culture plates (Corning, New York, USA). The isolates were kept in F/2 without silica 
124 (Guillard and Ryther 1962, Guillard 1975) made up with enriched sterile filtered seawater

125 from the site and kept at $18^{\circ} \mathrm{C}$ temperature, 12:12 light:dark cycle and the irradiance in the

126 incubator was $150 \mu \mathrm{mol}$ photon $\mathrm{m}^{-2} \mathrm{~s}^{-1}$ measured using an Iso-tech ILM350 light meter (ISO-

127 tech, Merseyside, UK). Potential AZA toxin producer isolates were discriminated from the 20

$128 \mu \mathrm{m}$ filtrate and $3 \mu \mathrm{m}$ backwash concentrated fractions by screening for morphological

129 characteristics typical of $A$. spinosum. Four other isolates apart from SM2 suspected to be $A$.

130 spinosum were isolated and cultured successfully based on cell size and shape, presence of

131 thecal plates, cell movement, and presence of antapical spine, presence/absence of a

132 conspicuous pyrenoid and presence/absence of apical pore. After successful isolation, the

133 unialgal cultures were transferred to $25 \times 150 \mathrm{~mm}$ borosilicate culture tubes (Fisherbrand ${ }^{\mathrm{TM}}$,

134 Loughborough, UK) containing $35 \mathrm{ml}$ of F/2 media and kept in the incubator in the

135 conditions as outlined before.

136

137 All cultured isolates were tested for the production of AZA toxins using LC-MS/MS, $1 \mathrm{ml}$

138 culture aliquots of a densely growing culture were collected using a $1 \mathrm{ml}$ pipette and placed

139 into $0.2 \mu \mathrm{m}$ Whatmann Anopore ${ }^{\mathrm{TM}}$ spin filter, the filters were centrifuged at $14000 \mathrm{rpm}$ for

140 one minute using a Heraeus Multifuge 3S-R (Heraeus, Hanau, Germany) and the filter

141 extracted using methanol.

\section{$143 \quad 2.2$ Microscopy}

144 2.2.1 Light microscopy $(L M)$

145 Observation of live cultured isolates was carried out using an inverted microscope (Axiovert

146 200M, Zeiss, Germany) equipped with epifluorescence and differential interference contrast

147 optics. Light microscopic examination of the thecal plate was performed as per Tillmann et

148 al. 2010 


\subsubsection{Scanning electron microscopy (SEM)}

152 The material for examination was collected from the unialgal cultures and prepared following

153 the protocol for SEM by Tillmann et al. 2009 with slight variations: the cell pellet -after resuspension and removal of $40 \%$ seawater -was fixed with formalin ( $2 \%$ final concentration) instead of glutaraldehyde in cacodylate buffer and stored in the fridge for $2 \mathrm{~h}$ before washing and dehydration steps. The filters were mounted on stubs, sputter coated (Emscope SC 500, Ashford, UK) with gold-palladium and viewed under a scanning electron microscope (FEI Quanta FEG 200, Eindhoven, Netherlands).

\subsection{Chemical analysis of the azaspiracids producing culture}

\subsubsection{Solvents and reagents}

162 Acetonitrile and methanol were purchased as pestican grade solvents from Labscan (Dublin,

163 Ireland). Formic acid, ammonium formate, ammonium hydroxide and sodium hydroxide were purchased from Sigma Aldrich (Steinheim, Germany). Hydrochloric acid was purchased from VWR (England). Water was obtained from a reverse-osmosis purification system (Barnstead, Dublin, Ireland). AZA certified reference materials (CRM) were obtained from the NRC (Halifax, Canada).

\subsubsection{Toxin extraction}

170 The culture was extracted by solid phase extraction (SPE). An Oasis HLB, 3 cc cartridge was

171 initially conditioned with $5 \mathrm{ml}$ of methanol, flushed with $10 \mathrm{ml}$ of a $5 \%$ methanol solution (in

172 water) and then loaded with $10 \mathrm{ml}$ of culture slowly (drop wise). The cartridge was flushed

173 again with $10 \mathrm{ml}$ of a $5 \%$ methanol solution followed by toxin elution with $4 \mathrm{ml}$ of methanol. 
174 The methanol extract was blown down to dryness, reconstituted back up in $0.5 \mathrm{ml}$ of

175 methanol and transferred into a HPLC vial for analysis.

$176 \quad$ 2.3.3 Analysis by LC-MS/MS

177 Analysis of AZAs was performed on a Micromass triple stage quadrupole (TSQ) Ultima

178 coupled to a Waters 2695, equipped with a Z-spray ESI source. The TSQ was operated in

179 positive ionization mode through multiple reactions monitoring (MRM). The following

180 transitions were monitored: AZA1 $\mathrm{m} / \mathrm{z}$ 842.5>654.4 and 842.5>672.4, AZA2 856.5>654.4

181 and 856.5>672.4, AZA3 828.5>640.4 and 828.5>658.4, AZA6 842.5>640.4 and

$182842.5>658.4$, AZA17 872.5>640.4 and 872.5>658.4 and AZA19 886.5>640.4 and

$183886.5>658.4$ in positive ionisation mode. The cone and collision voltages were set at $60 \mathrm{~V}$

184 and $40 \mathrm{~V}$ respectively. Cone and desolvation gas flows were set at 100 and $800 \mathrm{~L} / \mathrm{h}$,

185 respectively, while the source and desolvation temperatures were set at $150{ }^{\circ} \mathrm{C}$ and $350{ }^{\circ} \mathrm{C}$

186 respectively.

187

188 A binary mobile phase was used, phase A (100\% aqueous) and phase B (95\% aqueous

189 acetonitrile), both containing $2 \mathrm{mM}$ ammonium formate and $50 \mathrm{mM}$ formic acid. HPLC

190 separation was achieved using a Hypersil BDS C8 column; 50 x 2.1, $3 \mu \mathrm{m}$; guard column, 10

$191 \times 2.1 \mathrm{~mm}, 3 \mu \mathrm{m}$ (Thermo Scientific, Runcorn, UK). The flow rate was set at $0.25 \mathrm{ml} / \mathrm{min}$ and

192 the injection volume was set at $5 \mu$ l. The column and sample temperatures were set at $25^{\circ} \mathrm{C}$

193 and $6{ }^{\circ} \mathrm{C}$ respectively. A gradient elution was employed, starting with $30 \% \mathrm{~B}$, rising to $90 \%$

$194 \mathrm{~B}$ over $8 \mathrm{mins}$, held for $2.5 \mathrm{~min}$, then decreased to $30 \% \mathrm{~B}$ in $0.5 \mathrm{~min}$ and held for $4 \mathrm{~min}$ to

195 equilibrate the system.

196

197 2.4 Molecular phylogenetic analysis

198 2.4.1 Extraction of genomic DNA 
199 A $50 \mathrm{ml}$ sample of exponentially growing culture was centrifuged (Eppendorf 5810R,

200 Hamburg, Germany) at 3,220 x g for $15 \mathrm{~min}$ at room temperature. The cell pellets were

201 frozen at $-20{ }^{\circ} \mathrm{C}$ for 20 min before being subjected to total DNA extraction with the DNeasy

202 Kit (Mini) (Qiagen, Hilden, Germany) according to manufacturer's instructions. The purity

203 and quantity of the DNA was checked by UV-spectroscopy with a NanoDrop ND-1000

204 system (Peqlab, Erlangen, Germany) and the integrity of DNA fragments of a molecular 205 weight of about $20 \mathrm{~kb}$ was verified on a $1 \%$ agarose gel.

206

207

\subsubsection{PCR amplification and sequencing}

208 The total extracted DNA from the isolate was subjected to polymerase chain reaction (PCR) 209 amplification of the 28S ribosomal DNA.The forward and reverse primers for amplification of 28S rDNA (D1-D2 regions) were: Dir-F (5'- ACC CGC TGA ATT TAA GCA TA - 3')

211 and Dir-2CR (5'- CCT TGG TCC GTG TTT CAA GA - 3'), respectively. For the $50 \mu 1$ PCR

212 reaction, HotMasterTaq^^ ${ }^{\circledR}$ (Eppendorf, Hamburg, Germany) buffer $1 \mathrm{X}, 0.1 \mathrm{mM}$ of dNTPs,

$2130.1 \mathrm{mM}$ of each forward and reverse primer and 1.25 units of Taq polymerase were added to

$21410 \mathrm{ng}$ of the extracted genomic DNA. For 28S rDNA amplifications, the reactions were

215 subjected to the following thermocycling conditions: an initial denaturation at a temperature

216 of $95{ }^{\circ} \mathrm{C}$ for 7 min was followed by 35 cycles of denaturation at $94{ }^{\circ} \mathrm{C}$ for 45 seconds,

217 annealing temperature at $54{ }^{\circ} \mathrm{C}$ for $2 \mathrm{~min}$ and elongation temperature at $72{ }^{\circ} \mathrm{C}$ for $1.5 \mathrm{~min}$. A

218 final extension step at $72{ }^{\circ} \mathrm{C}$ was carried out for $10 \mathrm{~min}$. The completed reactions were kept

219 at $10{ }^{\circ} \mathrm{C}$ until the next step. The PCR amplicons were analysed on $1 \%$ agarose by

220 electrophoresis. Sequencing was conducted with a standard cycle sequencing chemistry ABI

2213.1 (Applied Biosystems, Darmstadt, Germany) using the PCR primer sets. Cycle sequencing

222 products were analyzed on an ABI 3130 XL capillary sequencer (Applied Biosystems,

223 Darmstadt, Germany) 


\subsubsection{Sequence alignment for phylogenetic analyses}

226 Sequence alignment was done with CLUSTAL X software (Thompson et al., 1997) and improved manually for all sequences; ambiguous alignments positions were excluded from the analysis. Alignments are available upon request and sequences are available at GenBank under accession number for LSU: SM2 XXXXXXXX. Maximum likelihood phylogenetic tree was calculated with PhyML (Guindon \& Gascuel, 2003) using a BIO-NJ (neighbourjoining) tree as a starting tree, and the general time reversible (GTR) nucleotide substitution model (Whelan \& Goldman, 2001) with a gamma distribution parameter estimated from the data, bootstrap analysis was performed with 100 replicates. The dinoflagellate Oxyrrhis marina (Dujardin) was selected as the outgroup.

\subsection{Blue Mussels feeding experiment}

\subsubsection{Experimental design}

A batch of approximately $10 \mathrm{~kg}$ of M.edulis were harvested from Carlingford Lough, Greenore (Lat: $54.0339^{\circ} \mathrm{N}$, Long: $-6.1417 \mathrm{~W}$ ) in the East coast of Ireland. The mussels were cleaned of all fouling organisms and placed in 20L clear plastic carboys filled with sterile filtered seawater (30 psu salinity) in the walk-in incubator at $18^{\circ}$ Celsius. Any dead mussels were removed from the carboys. The experiment consisted of a $24 \mathrm{~h}$ feeding experiment with M. edulis and the azaspiracids producing dinoflagellate A.spinosum at three cell densities to study feeding activity, toxin uptake and bioconversion of toxins in the shellfish digestive system. The cultures of A.spinosum and the mussels were maintained under the same environmental conditions for a week before the experiment was carried out.

247 Triplicate treatments were prepared in $5 \mathrm{~L}$ borosilicate conical flasks (Lennox, Dublin,

248 Ireland) at three cell densities; 30000cells ml ${ }^{-1}, 20000$ cells ml $\mathrm{m}^{-1}$ and 5000 cells $\mathrm{ml}^{-1}$ of $A$. 
249

250

251

252

253

254

255

256

257

258

259

260

261

262

263

264

265

266

267

268

269

270

271

272

273

spinosum. The mussels used in this study were weighed, measured and labelled before the start of the experiment; $100 \mathrm{~g}$ of mussels whole flesh was dissected from the batch of mussels for LC-MS/MS analysis to test for AZAs in the mussels prior to the experiment. Also, a sample of seawater $(50 \mathrm{ml})$ used for growing A.spinosum culture before inoculation of the algae was extracted for AZA toxins using a SPE column as described above in 2.3.2. The feeding experiment consisted of three mussels placed in each conical flask containing A.spinosum. Two control samples were set up, one containing three mussels with no algal suspension and one containing algal suspension with no mussels. The latter control was prepared to account for potential decline of algae in the water column due to sedimentation. 3 $\mathrm{X} 10 \mathrm{ml}$ suspension samples from each of the flasks were collected using an automated pipette (Hirsmann Laborgerate, Heilbronn, Germany) to measure the initial cell density and AZA toxin concentration. During the first two hours of the experiment, $1 \mathrm{ml}$ aliquots of seawater were collected from each flask every $20 \mathrm{~min}$. using a $1 \mathrm{ml}$ pipette (Eppendorf, Cambridge, UK) and preserved with lugol's iodine (Clin-tech, Dublin, Ireland) $1 \%$ final concentration to estimate cell concentrations of A.spinosum during the experiment. After two hours samples were collected every hour and finally at $24 \mathrm{~h}$. A final suspension sample $(10 \mathrm{ml})$ was collected at $24 \mathrm{~h}$ to analyse the final toxin content of remaining algal cells or other particles in the water column.

Pseudo-faeces and faeces excreted by the mussels during the experiment were harvested using $25 \mathrm{ml}$ serological pipettes (Sardstedt, Nümbrecht, Germany) and filtered after $24 \mathrm{~h}$ using GF/C Whatman $(1.2 \mu \mathrm{m}, 47 \mathrm{~mm}$ diameter $)$ glass microfiber filters under vacuum for toxin analysis to determine the total toxin budget for the experiment. Before harvesting, the water was removed from the flasks carefully avoiding the re-suspension of the faeces and pseudo-faeces, while most of the water was removed, a small amount of water was left at the 
274 bottom of the flasks and picked up in the pipette before filtering, which means that it is

275 possible that other material was present in the sample other than the faeces and pseudo-

276 faeces. The hypothesis here would be that since the algal suspension was depleted after $24 \mathrm{~h}$,

277 no A. spinosum cells are believed to be present in the water at this point.

278

279

\subsubsection{Azadinium spinosum cell counts}

280 Cell counts of the $1 \mathrm{ml}$ lugol's preserved aliquots were carried out using a Sedgewick-Rafter

281 cell counting chamber (Pyser-SGI, Kent, UK) for each flask at each time interval using an

282 inverted optical microscope Leica DMI 6000B (Leica, Wetzlar, Germany).

\subsubsection{Dissection of mussels and toxin analysis of shellfish tissues}

285 After $24 \mathrm{~h}$, the mussels were harvested from the flasks, weighed and dissected into hepatopancreas (HP) and remainder tissues. The dissected HP and remainder were placed into labeled $15 \mathrm{ml}$ polypropylene centrifuge tubes (Sardstedt, Nümbrecht, Germany). A volume of $1.5 \mathrm{ml}$ methanol was added to each tube and the sample was homogenized using an Ultra-Turrax (T25 Basic IKA®-Werke, Germany) at 11,000 rpm for 1 min. Samples were then centrifuged in a Heraeus Multifuge 3S-R (Heraeus, Hanau, Germany) at 4,500 rpm for 5 mins. The supernatant was decanted into $5 \mathrm{ml}$ volumetric flasks (Hirsmann-Techcolor, Heilbronn , Germany) and this step repeated twice for each pellet. The volume was then

293 brought up to the mark using pestican grade methanol, inverted 5 times for each and filtered 294 through $0.22 \mu \mathrm{m}$ filters(Sartorius, Surrey, UK) into HPLC vials (AGB, Dublin, Ireland) to be run on the LC-MS/MS. 
298 The toxicity of A.spinosum cells was measured during the feeding experiment at two time 299 intervals. Triplicate $10 \mathrm{ml}$ samples of A. spinosum were collected from each flask in $15 \mathrm{ml}$

300 centrifuge tubes at initial time $\left(\mathrm{T}_{0}\right)$ and at the end of the experiment after $24 \mathrm{~h}$. The samples

301 were centrifuged at 4,500 rpm for $15 \mathrm{~min}$. The supernatant was decanted off and $500 \mu \mathrm{L}$ of

302 methanol was added to each pellet. Samples were then vortexed in a V400 Multitube Vortex

303 mixer (Alpha Laboratories, Hampshire, UK) mixed for 1 min at maximum speed then

304 centrifuged again. The supernatant was collected into labeled HPLC vials. The process was

305 repeated twice to obtain a final volume of $1.5 \mathrm{ml}$ for each HPLC vial. These samples were

306 blown down to dryness under nitrogen gas (BOC gases, Dublin, Ireland) and reconstituted

307 with $500 \mu \mathrm{L}$ methanol to be analysed by LC-MS/MS.

308

$309 \quad$ 2.5.5 Toxin analysis of biodeposits

310 After harvesting the mussels from the flasks, biodeposits (pseudo-faeces, faeces and any

311 detritus left in the flask and a small amount of water) were collected from the bottom of the

312 flasks and then filtrated on GF/C Whatman $(1.2 \mu \mathrm{m}, 47 \mathrm{~mm}$ diameter $)$ glass microfiber

313 filters. Filters from each flask were placed into labeled $50 \mathrm{ml}$ centrifuge tubes. A volume of

$3143 \mathrm{ml}$ methanol was added to each tube and vortex mixed at maximum speed for $1 \mathrm{~min}$.

315 Samples were then centrifuged at $3,500 \mathrm{rpm}$ for $15 \mathrm{~min}$ at $4{ }^{\circ} \mathrm{C}$. The supernatant was

316 transferred to $10 \mathrm{ml}$ volumetric flasks. This was repeated twice and the volume was made up

317 to the mark using methanol. The flasks were inverted 5 times and filtered through $0.22 \mu \mathrm{m}$

318 filters into HPLC vials to be analysed via LC-MS/MS using the conditions described

319 previously.

320

3213 . Results and discussion

3223.1 Azadinium spinosum Irish strain 
323 The armoured dinoflagellate A. spinosum has been described by Tillmann et al. 2009 as a

324 new species and a new genus. Since then, two additional but non-toxic species have been described, A.obesum (Tillmann et al. 2010) and A.poporum (Tillmann et al. 2011). The Irish isolate provisionally named SM2, clearly is a new geographical strain of A.spinosum as it is sharing all morphological details compiled by Tillmann et al. $(2009,2011)$ to describe A.spinosum and to differentiate this species from the two other species.

Figure 2A depicts a light microscopy image of the Irish strain of A.spinosum showing the main morphological characteristics typical of the species, a conspicuous Apical Pore Complex (APC), a conspicuous pyrenoid (P) in the episome which can be used to differentiate A. spinosum from A.obesum, the large spherical nucleus (N) posteriorly located and the antapical spine (S).This antapical spine situated in the second antapical plate is an important feature for the identification of the species as it is present in A. spinosum but lacking in the two other described species, A obesum and A. poporum (Tillmann et al. 2010, 2011). For the Irish strain SM2, the spine was visible using X100 oil immersion objectives under the light microscope in formalin preserved water samples, although it was difficult enough to discern.

Anyhow, the best way to visualise the spine and distinguish the delicate thecal plates in this

342 dinoflagellate is to use Scanning Electron Microscopy (SEM) which allowed us to identify

343 the plate tabulation to be Po, cp, X, 4', 3a, 6', 6C, 5?S, 6',', 2',', which is the same as reported in Tillmann et al. 2009. Figure 2B \& C show complete cells of A.spinosum. In ventral view (Fig.2B) the ventral pore (vp) is clearly visible in the left suture of the first apical plate, the thecal plates cleaned of the outer membrane appear smooth and some scattered pores can be seen on the plates. Figure 3B shows the three intercalary plates on the 
episome of the cell; the second intercalary plate (2a) is smaller than the other two plates and is located above the third pre-cingular plate.

Figure $3 \mathrm{C}$ shows the complete epithecal plates of $A$. spinosum, the detail view of the APC (Fig 3D) shows an identical configuration of the pore described for A. spinosum and A.obesum (Tillmann et al. 2010). The apical pore located centrally in the pore plate (Po) which is topped by the cover plate (cp). The X plate is situated between the first apical and the pore plate which protrudes and extends to touch the cover plate.

The sulcal plates (Fig. 4A \& B) were determined by SEM and we can distinguish 5 plates from the outer side of the theca. The anterior sulcal (Sa) plate is large and roughly the same height as the width of the cingulum, the right sulcal $(\mathrm{Sd})$ and median sulcal $(\mathrm{Sm})$ plates form an intricate cavity around the emerging point of the flagella with the left sulcal (Ss) plate extending from the cingulum where it touches the first cingular $(\mathrm{C} 1)$ and Sa plates then follows the contour of the Sm and Sd on the left side and finally touches the Sulcal posterior (Sp) in the hypotheca. The cingulum is wide and composed of 6 cingular plates (Fig. 4A \& C).The hypothecal plates can be seen from the antapical view in figure 4D, 6 post-cingular and 2 antapical plates with the spine positioned in the second antapical plate.

\subsection{Azaspiracid composition and content in culture}

The cultured Irish strain SM2 of A.spinosum produces the azaspiracid analogues AZA1 and 2. AZA1 is the major toxin component in the sample and AZA2 is found at lower concentrations. The cell quota from parallel cultures kept in the same conditions as the culture used for the feeding experiment ranged from $\sim 15$ to $25 \mathrm{fg} / \mathrm{cell}$ for AZA1 and $\sim 1$ to $5 \mathrm{fg} / \mathrm{cell}$ for AZA2 (data not included). This toxin profile correlates with that found by Krock 
373 et al., 2009 in the 3D9 isolate from the Scottish coast. Krock, also reported a potential new

374 analogue (AZAx) which was later found to be an extraction (with methanol) artefact,

375 personal comms.

$376 \quad 3.3$ Molecular genetic analysis

377 We amplified and sequenced the D1-D2 regions of the nuclear ribosomal RNA gene from

378 strain SM2. The sequenced region encompassed 436 base pairs, and was exactly identical to 379 the homologous sequences from two previously characterized A. spinosum strains (strains 380 3D9 and UTHE2), and differed in 10 and 8 substitutions from sequences available from $A$. 381 poporum and A. obesum, respectively (Figure 5).

382

$383 \quad 3.4$ Feeding experiment

384 3.4.1 Mussels feeding activity

385 All mussels started feeding after a few minutes of being introduced into the flasks containing 386 the algae; this continued for the $24 \mathrm{~h}$ that the experiment lasted. Figure 6 illustrates the

387 decreasing concentration of algae in the different treatments over $24 \mathrm{~h}$. The control line

388 demonstrates that sedimentation of the algal suspension in the control treatment during the 389 experiment was negligible. The data suggest that most of the algae have been consumed

390 within three hours of commencement of the experiment, low baseline algal cell

391 concentrations below $\sim 3000$ cells $\mathrm{ml}^{-1}$ were found after $5 \mathrm{~h}$ in the 30000 cells $\mathrm{ml}^{-1}$ treatment,

$392 \sim 850$ cells ml$l^{-1}$ in the 20000 cells ml${ }^{-1}$ treatment and $\sim 67$ cells ml$^{-1}$ in the 5000 cells ml $^{-1}$

393 treatment and after $24 \mathrm{~h}$ the estimates were $\sim 73$ cells ml$^{-1}, \sim 50$ cells ml${ }^{-1}$ and $\sim 4$ cells ml$^{-1}$ 394 respectively.

396 During feeding, all individual mussels were observed to produce pseudo-faeces in all

397 treatments. The amount of pseudo-faeces produced appeared to slow down after 
398

399

400

401

402

403

404

405

406

407

408

409

410

411

412

413

414

415

416

417

418 The amount of AZA1 in both the 30000 cells ml ${ }^{-1}$ treatment and the 20000 cells ml${ }^{-1}$

419 treatment was already above the regulatory limit for AZA equivalent toxins suggesting that

421

422

approximately one hour, while some faeces were also produced after approximately two hours. One mussel in one of the 30000 cells ml$^{-1}$ treatment replicates started spawning after two hours copiously but continued filtering afterwards, which could suggest some level of stress however this appeared to be an isolated episode.

\subsubsection{Shellfish azaspiracid toxin analysis}

The mussels and the media used for this experiment were analysed by LC-MS/MS for AZAs to demonstrate that there weren't any toxins initially in the seawater used to grow the algae or in the shellfish tissue prior to carrying out the feeding experiment. Both controls were below the limit of quantification (LOQ) for AZAs. Also, a control using mussels without algal suspension throughout the $24 \mathrm{~h}$ experiment was analysed using LC-MS/MS and found to be negative for AZAs (data not included).

After $24 \mathrm{~h}$ the mussels were harvested, dissected and analysed via LC-MS/MS. Figure 7 shows the concentration of AZA toxins detected in the mussels hepatopancreas for each treatment. In all treatments, significant amounts of AZA1and AZA2 were found in the mussels with considerably higher concentrations for the two highest cell concentrations of A.spinosum compared to the lower concentration. This demonstrates that mussels do ingest A.spinosum directly and accumulate AZA toxins in their digestive system with toxicity being related to the density of the algae in the water. mussels can become intoxicated with AZAs at A.spinosum cell concentrations of 20000 cells $\mathrm{ml}^{-1}$ over a $24 \mathrm{~h}$ period. The concentration of AZA1 and -2 toxins is higher in the HP tissue compared to the toxin concentration found in the remainder with negligible amounts between 
423 the limit of detection $\left(0.01 \mu \mathrm{g} \mathrm{g}^{-1}\right)$ and the limit of quantification for the instrument $(0.02 \mu \mathrm{g}$

$424 \mathrm{~g}^{-1}$ ) with the highest amount detected $\sim 0.015 \mu \mathrm{g} \mathrm{g}^{-1}$ of AZA1 in the 20000 cells $\mathrm{ml}^{-1}$

425 treatment. The concentration of the toxin analogue AZA3 in the mussel HP was below the

426 limit of quantification suggesting that the decarboxylation of AZA17 to AZA3 probably

427 occurs over a longer period of time than $24 \mathrm{~h}$.

428

429

430

3.4. 3 Azaspiracid toxin analogues results

431 The amount of toxins found varied significantly between mussels, replicates and treatments;

432 this is possibly due to normal physiological differences like size, weight, age and condition of

433 the mussels. We found that AZA1 and -2 toxins were already bioconverting into their

434 carboxylated analogues AZA17 and -19 within the first $24 \mathrm{~h}$.This is evidence that toxin

435 bioconversion takes place in the shellfish digestive tract quite rapidly. The ratio of AZA17 to

436 AZA1 toxins were found in all treatments $(n=9)$ on average to be $1: 1$ in the mussel

437 hepatopancreas.

438

439 High levels of AZA17 compared to AZA1were also found in the remainder tissue supporting

440 the study performed by O'Driscoll et al. 2010 (unpublished) which shows that the oxidation

441 process of AZA toxins occurs primarily in the gills. The ratio of AZA17 to AZA1 toxins in

442 the remainder tissues was approximately 5:1 in all treatments.

443

444 The screening of AZA17 in shellfish samples is not a monitoring requirement in the current

445 legislation as AZA17 is converted naturally to AZA3 in the shellfish over time, and it is not

446 thought to be a large component of the total AZA toxin content, however as this feeding

447 experiment indicates, it is possible that if mussels have been contaminated recently with 
448 AZAs, the amount of AZA17can equal that of AZA1 or even exceed that of AZA1 resulting

449 potentially in an underestimation of the total amount of AZA toxins in the samples. As

450 shellfish samples are analysed raw, AZA17 won't convert readily to AZA3 unless mussels

451 are cooked or the method incorporates a heating step in the extraction process.

452

$453 \quad 3.4 .4$ Toxin budget feeding experiment

454 The total toxin budget for the feeding experiment included the initial and final toxin content of the algal suspension, the toxin found in the mussel tissues (HP and remainder) and the toxin found in the biodeposits (faeces/pseudo-faeces). This budget doesn't include any extracellular dissolved toxin fraction. The budget measures the amount of the principal toxins AZA1 and -2, the oxidation analogues AZA17 and -19 and the decarboxylated analogues AZA3 and-6. The final toxin budget illustrated by the 30000 cells $\mathrm{ml}^{-1}$ treatment (Table 2) shows a high $\%$ recovery of toxins from the experiment accounting on average for $\sim 87 \%$ of AZA1 and AZA2 of the initial toxin content in the algal suspension, 36\% of AZA1 and $34 \%$ of AZA2 were recovered in the mussel tissues and $~ 16 \%$ of AZA1 and $21 \%$ of AZA2 were found in the biodeposits which indicates some level of toxin excretion, however, after $24 \mathrm{~h} \sim 35 \%$ of AZA1and $\sim 32 \%$ of AZA2 toxins were still found in the final water samples which at this point should only contain baseline cell densities of $A$.spinosum suggesting that some toxins were possibly re-suspended from the biodeposits due to aeration, so it is possible

467 that the amount of toxins in the biodeposits could be larger than the reported budgets. The 468 remaining $\sim 13 \%$ of AZA1and AZA2 were not accounted for.

470 The toxin budget of the 20000 cells ml$^{-1}$ and $5000 \mathrm{cells} \mathrm{ml}^{-1}$ treatments (supplementary 471 material) returned a recovery above 100\%, 113\% AZA1 and $\sim 120 \%$ AZA2 in the 20000 472 cells $\mathrm{ml}^{-1}$ budget and $\sim 150 \%$ AZA1 and $175 \%$ AZA2 in the 5000 cells ml $^{-1}$ budget. The high 
473 recovery in the 5000 cells $\mathrm{ml}^{-1}$ treatment could be explained by the lower toxin content and

474 the uncertainty in the measurement of the AZA peaks at these concentrations. The recovery

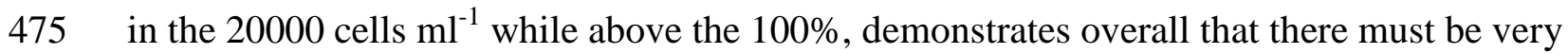

476 little loss of toxins into the dissolved phase in any case. This latter point is only hypothetical

477 as we have not calculated the dissolved fraction for this experiment.

478

\section{Conclusions}

480 Based upon the morphological characteristics described and the Kofoidean tabulation of the 481 recently isolated AZA toxin producer Irish strain SM2 we can conclude that the Irish isolate

482 fits perfectly with the description of A. spinosum. The sequence of the variable D1-D2

483 regions of the nuclear LSU rDNA of the Irish strain SM2 is also identical to those available

484 from the Scottish 3D9 and Danish UTHE2 strains, further supporting their conspecificity.

485 This is the third strain of A.spinosum reported to produce AZAs from a different geographical 486 location in the North Atlantic after the discovery of the 3D9 isolate from the Scottish coast 487 and the UTH E2 isolate from the Danish coast (Tillmann et al., 2009, 2011). So far no other 488 species of the genus Azadinium that have been tested to date have produced AZAs other than 489 the type species A.spinosum. From a monitoring perspective this organism is very small and 490 difficult to identify to species level in preserved water samples, yet using a good research 491 compound microscope fitted with oil immersion lenses, it is possible to view several 492 important morphological features that describes this species, in particular the antapical spine, 493 which is typical of A.spinosum. While this feature provides reliable identification of the 494 species together with other morphological characteristics typical of the genus, it will be 495 ultimately the development of gene probes that will prove a useful tool in the future of 496 monitoring, quantification and identification of the genus. Molecular methods however may 497 yet take some time to become available for real time monitoring as this genus is still only 
recently discovered and the continued discovery of new species of Azadinium and strains of A.spinosum and other species in this size range, means that gene probes will have to be exhaustedly tested for cross reactivity between the genus and within the different strains before they can be relied upon.

502

503 Here we have for the first time proof of a direct toxin transfer of AZA toxins from

504 A.spinosum by feeding M. edulis without the need for vector species. Mussels will actively

505 filter, ingest, accumulate and bioconvert azaspiracid toxins quite readily into other AZA 506 analogues. AZA1 and -2 were found to be concentrated mainly in the HP tissue whereas 507 AZA17 and -19 were distributed throughout the whole flesh. The results show that the ratio 508 of AZA17 in the remainder tissue can be up to five or six times the amount of AZA1. AZA17 509 is known to convert readily to the decarboxylated analogue AZA3 upon cooking, however 510 monitoring samples are analysed raw and the analogue AZA17 is not monitored as the

511 present legislation only sets limits for the forms AZA1, AZA2 and AZA3. This means that 512 the total AZA toxin content in shellfish samples could be underestimated. The toxin budget 513 indicated that most of the AZA toxins detected in the plankton can be accounted for in the 514 shellfish tissues, the biodeposits and the particulates in the water suggesting that the dissolved 515 fraction of AZAs in the water should be quite small. These results illustrate the need for 516 further experiments in the kinetics of the principal plankton AZA toxins in shellfish tissues.

\section{Acknowledgments}

519 This project (Grant-Aid Agreement No.PBA/AF/08/001(01)) was carried out under the 520 Sea Change strategy with the support of the Marine Institute and the Marine Research 521 Sub-Programme of the National Development Plan 2007-2013, co-financed under the 522 European Regional Development Fund. 
523 We would like to thank also Marine Institute staff in the Phytoplankton, and biotoxin sections

524 for the help with culturing, and use of LC-MS/MS. Tara Chamberlain from the phytoplankton

525 lab in Bantry for her help collecting and processing water samples and Mike Sammon in

526 Bantry for his help with boats and deployment of equipment during sampling trips to Bantry

527 bay. Ger Clancy and Daniel O'Driscoll for their help on the feeding experiment experimental

528 design and advice on the metabolism of azaspiracids.

529

$530 \quad$ References

531 Alvarez, G., Uribe, E., Avalos, P., Mariño, C. and Blanco, J. 2009. First identification of

532 azaspiracid and spirolides in Mesodesma donacium and Mulinia edulis from Northern Chile.

533 Toxicon 55: 638-641.

534

535 Furey, A., Braña Magdalena, A., Fidalgo Saez, M.J. Lehane, M. and James, K.J., 2003.

536 Geographical, temporal, and species variation of the polyether toxins, azaspiracids, in

537 Shellfish. Environ. Sci. Technol. 37: 3078-3084.

538

539 Fux, E., Bire, R. and Hess, P., 2009. Comparative accumulation and composition of lipophilic

540 marine biotoxins in passive samplers and in mussels Mytilus edulis on the west coast of

541 Ireland. Harmful algae 8: 523-537.

542

543 Guindon, S. and Gascuel, O., 2003. A simple, fast and accurate algorithm to estimate large

544 phylogenies by maximum likelihood. Syst. Biol., 52:696-704.

545

546 James, K.J., Furey, A., Satake, M., Yasumoto, T., 2000. Azaspiracid poisoning (AZP): a new

547 shellfish toxic syndrome in Europe. In: Hallegraeff, G.M., Blackburn, S.I., Bolch, C.J.S., 
548 Lewis, R.J. (Eds.), Ninth International Conference on Harmful Algal Blooms. International

549 Oceanographic Commission of UNESCO, Paris, France, PP. 250-253.

550

551 James, K. J., Furey, A., Lehane M., Ramstad, H., Aune, T., Hovgaard, P., Morris, P.,

552 Higman, W., Satake, M. and Yasumoto, T., 2002. First evidence of an extensive northern

553 European distribution of azaspiracid poisoning (AZP) toxins in shellfish. Toxicon 40: 909554915.

555

556 James, K.J., Sierra, M.D., Lehane, M., Braña Magdalena, A. and Furey, A., 2003. Detection

557 of five new hydroxyl analogues of azaspiracids in shellfish using multiple tandem mass

558 spectrometry. Toxicon 41: 277-283.

559

560 Kofoid, C.A. 1909. On Peridinium stenii Jörgensen, with a note on the nomenclature of the

561 skeleton of the Peridinidae. Arch. Protistenkt. 16: 25-47.

562

563 Krock, B., Tillmann, U., John, U. Cembella, A.D., 2009. Characterization of azaspiracids in

564 plankton size-fractions and isolation of an azaspiracid-producing dinoflagellate from the

565 North Sea. Harmful algae 8: 254-263.

566

567 Lopez-Ribera,A., O’Callaghan, K., Moriarty, M., O’Driscoll, D., Halmiton, B., James, K.J., 568 Furey, A., 2010. First evidence of azaspiracids (AZAs): A family of lipophilic polyether

569 marine toxins in scallops (Argopecten purpuraturs) and mussels (Mytilus chilensis) collected 570 in two regions of Chile. Toxicon 55 (4): 692-701. 
571 McCarron, P., Kilcoyne, J., Miles, C.O. and Hess, P., 2009. Formation of Azaspiracids-3, -4,

$572-6$ and -9 via decarboxylation of carboxyazaspiracid metabolites from shellfish. J. Agric.

573 Food Chem.

574

575 McMahon, T. and Silke, J., 1996. West coast of Ireland; winter toxicity of unknown aetiology

576 in mussels. Harmful algae News 14: 2.

577

578 Ofuji, K., Satake, M., McMahon, T., Silke, J., James, K.J., Naoki, H., Oshima,Y. and

579 Yasumoto, T., 1999. Two analogs of Azaspiracid isolated from mussels, Mytilus edulis,

580 involved in human intoxication in Ireland. Nat. Tox. 7, 99-102.

581

582 Ofuji, K., Satake, M., McMahon, T., James, K.J., , Naoki, H., Oshima, Y. and Yasumoto, T.,

583 2001. Structures of azaspiracid analogs, azaspiracid-4 and azaspiracid-5, causative toxins of

584 azaspiracid poisoning in Europe. Biosci. Biotech. Biochem. 65: 740-742.

585 Rehmann, N., Hess, P. and Quilliam, M.A., 2008. Discovery of new analogs of the marine

586 biotoxin azaspiracid in blue mussels Mytilus edulis by ultra-performance liquid

587 chromatography/tandem mass spectrometry. Rap.commun. Mass Spectrom 22: 549-558.

588

589 Perez R.; Rehmann, N.; Crain, S.; LeBlanc, P.; Craft, C.; MacKinnon, S.; Reeves, K.; Burton,

590 I.; Walter, J.; Hess, P.; Quilliam, M. A.; Melanson, J., 2010.The preparation of certified

591 calibration solutions for azaspiracid-1, -2 , and -3 , potent marine biotoxins found in shellfish.

592 Anal. Bioanal. Chem. 398, 2243-2252. 
594 Satake, M., Ofuji, K., Naoki, H., James, K.J., Furey, A., McMahon, T., Silke, J., and

595 Yasumoto, T., 1998. Azaspiracid, a new marine toxin having unique spiro ring assemblies,

596 isolated from Irish mussels, Mytilus edulis. J. Am. Chem. Soc. 120, 9967-9968.

597

598 Taleb, H., Vale, P., Amanhir, R., Benhadouch, A., Sagou, R., Chafik, A., 2006. First

599 detection of Azaspiracids in mussels in north west Africa. J. Shellfish Res. 25 (3), 1067-1070.

600 Tillmann, U., Elbrächter, M., Krock, B., John, U. and Cembella, A., 2009. Azadinium

601 spinosum gen. et sp. nov. (Dinophyceae) identified as a primary producer of azaspiracid

602 toxins. Eur. J. Phycol. 44(1): 63-79.

603

604 Tillmann, U., Elbrächter, M., John, U., Krock, B. and Cembella, A., 2010. Azadinium obesum

605 (Dinophyceae), a new nontoxic species in the genus that can produce azaspiracid toxins.

606 Phycologia 49(2):169-182.

607 Tillmann, U., Elbrächter, M. John, U. Krock, B. 2011. Azadinium poporum isolated from the

608 Danish west coast, a third - and second non-toxic - species in the genus that can produce

609 azaspiracids. Eur. J. Phycol., in press.

610

611 Thompson, J.D., Gibson, T.J., Plewniak, F., Jeanmougin, F. and Higgins, D.G., 1997. The

612 ClustalX windows interface: flexible strategies for multiple sequence alignment aided by 613 quality analysis tools. Nucl. Acid. Res., 25, 4876-4882.

614

615 Twiner, M.; Hess, P.; El-Ladki, R.; Butler, S.; Doucette, G. Toxicological Mechanisms of

616 Azaspiracid: An emerging algal toxin in US waters. Poster presentation in $14^{\text {th }}$ International

617 Conference in Harmful Algae, Hersonissos, Crete, Greece, 1-5 ${ }^{\text {th }}$ November 2010. 
619 Ueoka, R.; Ito, A.; Izumikawa, M.; Maeda, S.; Takagi, M.; Shin-ya, K.; Yoshida, M.; van 620 Soest, R. W. M.; Matsunaga, S., 2009. Isolation of azaspiracid-2 from a marine sponge 621 Echinoclathria sp. as a potent cytotoxin. Toxicon 53, 680-684.

622

623 Vale, P., Bire, R. and Hess, P., 2008. Confirmation by LC- MS/MS of azaspiracids in 624 shellfish from the Portuguese north-western coast. Toxicon 51: 1449-1456.

625

626 Whelan, S. and Goldman, N., 2001. A general empirical model of protein evolution derived

627 from multiple protein families using a maximum likelihood approach. Mol. Biol. Evol. 18: $628 \quad 691-699$. 
Table 1. Maximum concentration of AZA equivalents ( $\mathrm{mg} k \mathrm{~kg} 1$ ) found in shellfish species cultured in Ireland between 2003 and 2010 analysed using LC-MS/MS. LOQ, limit of quantification.

\begin{tabular}{|c|c|c|}
\hline \multicolumn{2}{|l|}{ Shellfish species } & \multirow{2}{*}{$\begin{array}{l}\text { Concentration } \\
\text { AZA-equiv. }\left(\mathrm{mg} \mathrm{kg}^{-1}\right)\end{array}$} \\
\hline Common name & Scientific name & \\
\hline Common Cockle & Cerastoderma edule & 0.08 \\
\hline Pacific oyster & Crassostrea gigas & 0.31 \\
\hline Razor clam & Ensis arcuatus & 0.05 \\
\hline Razor clam & Ensis siliqua & $<0.01$ \\
\hline Dog cockle & Glycymeris glycymeris & 0.01 \\
\hline Abalone & Haliotis discus hannai & $<\mathrm{LOQ}$ \\
\hline Blue mussel & Mytilus edulis & 8.97 \\
\hline Native oyster & Ostrea edulis & 0.07 \\
\hline Common limpet & Patella vulgata & $<\mathrm{LOQ}$ \\
\hline Surf Clam & Spisula solida & 0.15 \\
\hline Manila Clam & Tapes philippinarum & 0.10 \\
\hline Clam & Tapes semidescussatus & 0.01 \\
\hline Pullet carpet shell & Venerupis senegalensis & $<$ LOQ \\
\hline Venus Clam & Venus verrucosa & $<$ LOQ \\
\hline
\end{tabular}

Table 2. Azaspiracid toxins budget in the 30,000 treatment.

\begin{tabular}{|c|c|c|c|c|c|c|c|c|c|c|c|}
\hline \multirow{2}{*}{$\begin{array}{l}\text { Flasks } \\
\text { Replicates }\end{array}$} & \multirow{2}{*}{$\begin{array}{l}\text { Initial toxin culture (ng) } \\
\text { AZA1 }\end{array}$} & \multicolumn{2}{|c|}{ Final toxin culture } & \multicolumn{3}{|c|}{ Tissue after 24 h (ng) } & \multicolumn{3}{|c|}{ Biodeposits (ng) } & \multirow{2}{*}{$\begin{array}{l}\text { Total }(\mathrm{ng}) \\
\text { Total recovered }\end{array}$} & \multirow[t]{2}{*}{$\%$} \\
\hline & & AZA1 & AZA17 & AZA1 & AZA17 & AZA3 & AZA1 & AZA17 & AZA3 & & \\
\hline $30,000 \mathrm{~F} 1$ & 2291.67 & 708.33 & 5.61 & 414.18 & 371.10 & 32.45 & 454.00 & 6.32 & 3.36 & 1995.34 & 87.1 \\
\hline $30,000 \mathrm{~F} 2$ & 2258.33 & 808.33 & 172.23 & 136.61 & 370.84 & 25.32 & 285.00 & 9.17 & 1.83 & 1809.34 & 80.1 \\
\hline $30,000 \mathrm{F3}$ & 2500.00 & 625.00 & 68.44 & 292.07 & 480.13 & 32.76 & 391.00 & 7.91 & 2.26 & 1899.57 & 76.0 \\
\hline Mean & 2350.00 & 713.89 & 82.09 & 280.95 & 407.36 & 30.18 & 376.67 & 7.80 & 2.48 & 1901.41 & 81.1 \\
\hline \multirow{3}{*}{\multicolumn{11}{|c|}{$\begin{array}{l}\% \text { toxins in mussel tissue } \\
\% \text { toxins in suspended particulate matter } \\
\% \text { toxins in biodeposits }\end{array}$}} & 30.6 \\
\hline & & & & & & & & & & & 33.9 \\
\hline & & & & & & & & & & & 16.5 \\
\hline Replicates & AZA2 & AZA2 & AZA6 & AZA2 & AZA19 & AZA6 & AZA2 & AZA19 & AZA6 & Total recovered & \\
\hline $30,000 \mathrm{~F} 1$ & 312.62 & 121.17 & 0.00 & 86.20 & 29.95 & 0.00 & 58.56 & 0.85 & 0.00 & 296.74 & 94.9 \\
\hline $30,000 \mathrm{~F} 2$ & 263.84 & 103.14 & 0.00 & 35.06 & 29.31 & 0.00 & 50.95 & 1.61 & 0.00 & 220.07 & 83.4 \\
\hline $30,000 \mathrm{F3}$ & 348.87 & 71.39 & 0.00 & 69.32 & 43.88 & 0.00 & 79.10 & 1.58 & 0.00 & 265.28 & 76.0 \\
\hline Mean & 308.44 & 96.57 & 0.00 & 63.53 & 34.38 & 0.00 & 62.87 & 1.35 & 0.00 & 260.69 & 84.8 \\
\hline \multirow{3}{*}{\multicolumn{11}{|c|}{$\begin{array}{l}\% \text { toxins in mussel tissue } \\
\% \text { toxins in suspended particulate matter } \\
\% \text { toxins in biodeposits }\end{array}$}} & 31.7 \\
\hline & & & & & & & & & & & 32.0 \\
\hline & & & & & & & & & & & 20.8 \\
\hline
\end{tabular}




\section{Figures}

Figure 1. AZA equivalents concentration $\left(\mathrm{mg} \mathrm{kg}^{-1}\right)$ found in blue mussels (Mytilus edulis) in Ireland between 2003 and 2010. Please note that two data points are not shown in this table as the AZA equivalent concentrations were too high compare to the rest of the results and it would have caused the graph to collapse at the lower concentrations. The following data points are not shown (7.37 $\mathrm{mg} \mathrm{kg}^{-1}$ AZA-equiv. (22/08/05) and $8.97 \mathrm{mg} \mathrm{kg}^{-1}$ AZA-equiv. $(01 / 10 / 2005))$.

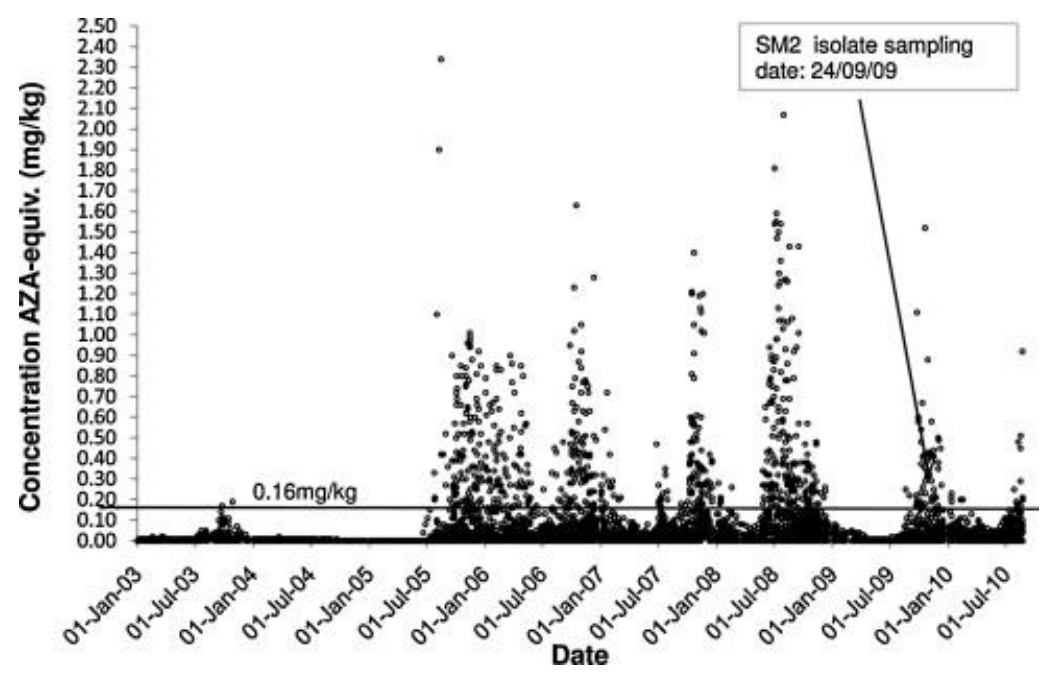

Figure 2. Azadinium spinosum (SM2 isolate). Light microscopy view (A) of live cell at 100x objective, SEM (scanning electron microscopy) micrographs of thecae (B) ventral view; (C) dorsal view. Scale bars: $5 \mu \mathrm{m}$. APC, apical pore complex; $\mathrm{P}$, pyrenoid; N, nucleus; S, spine.

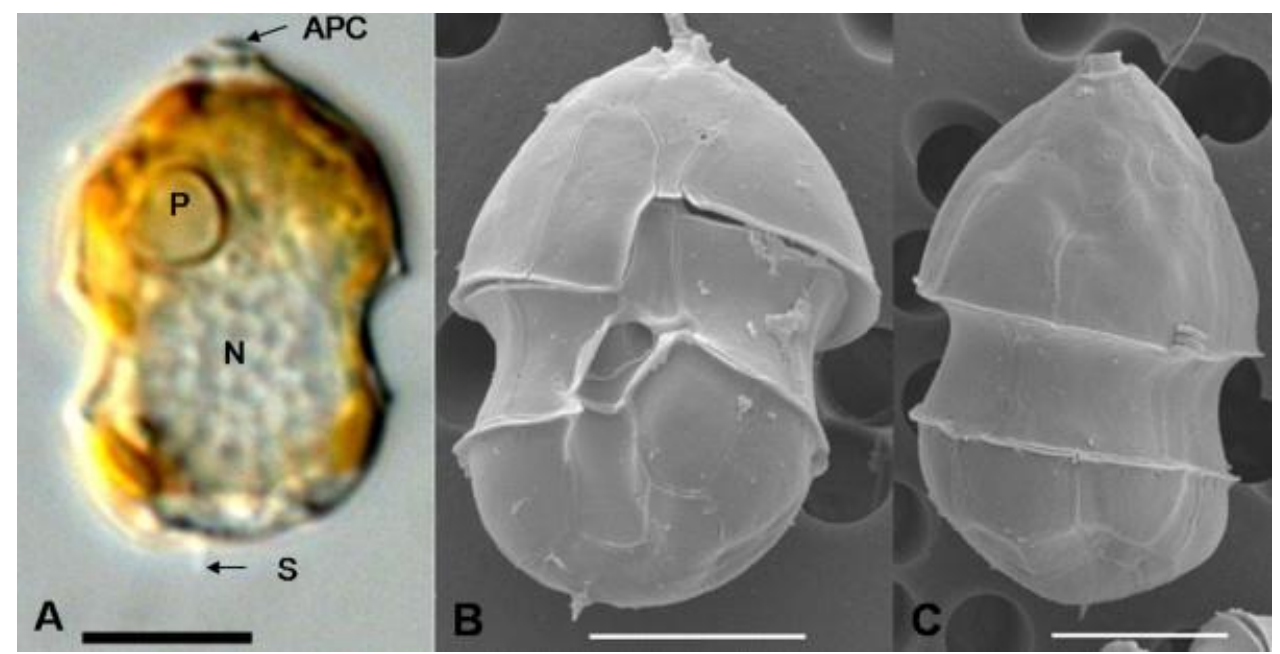


Figure 3. Azadinium spinosum (SM2 isolate). SEM micrographs of epithecal plates from different cells in (A) ventral view; (B) mid-dorsal view; (C) full epitheca from an apical view; (D) apical pore complex detail (APC). Scale bars: $2 \mu \mathrm{m}$ (Fig. 4A and C), $5 \mu \mathrm{m}$ (Fig. 4B) and $0.25 \mu \mathrm{m}$ (Fig. 4D).

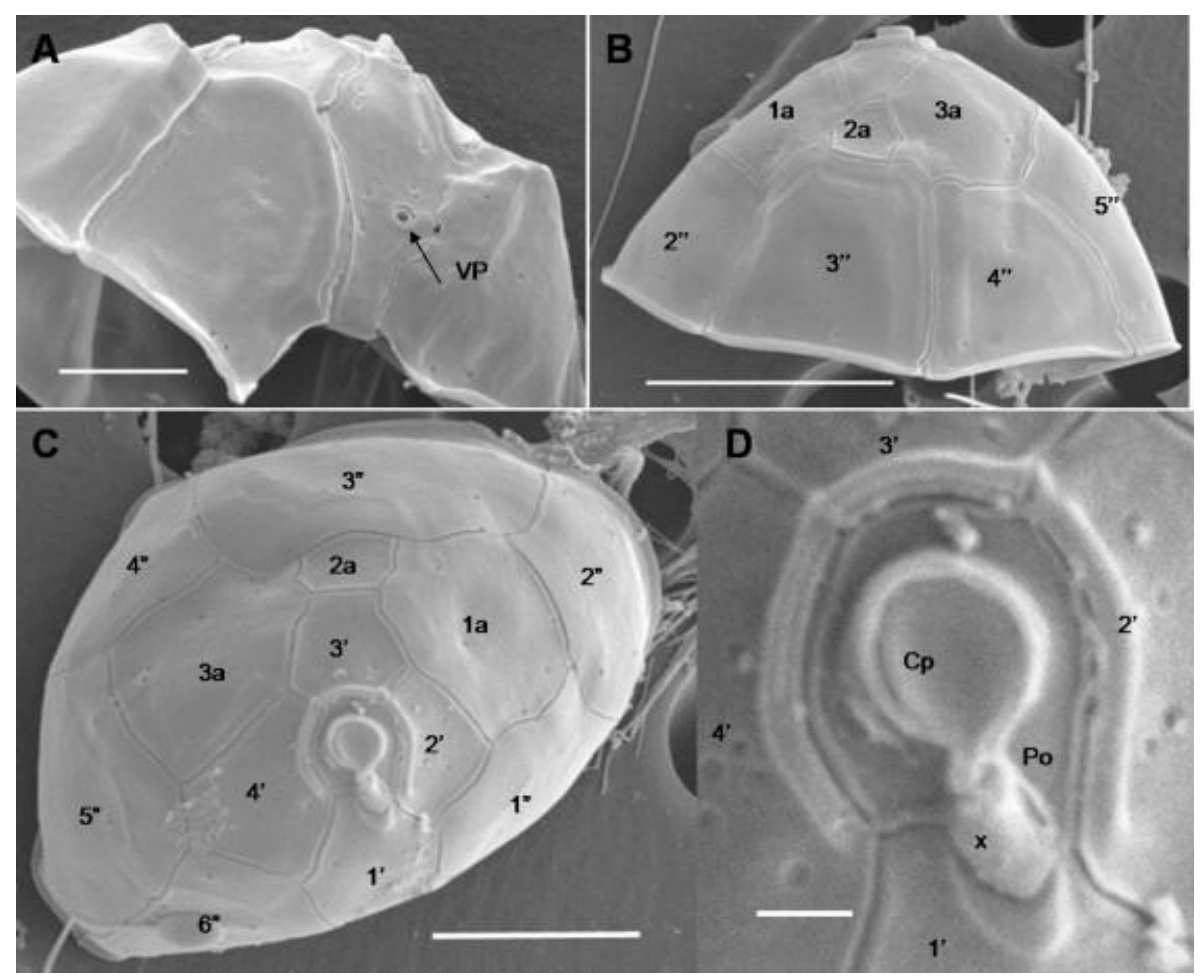


Figure 4. Azadinium spinosum (SM2 isolate). SEM micrographs of hypothecal plates from different cells showing details of hypotheca, cingulum and sulcus. (A) Hypotheca and cingulum in dorsal view; (B) detailed view of the sulcal region. Sa, anterior sulcal plate; Sm, median sulcal plate; Sd, right sulcal plate; Ss, left sulcal plate; Sp, posterior sulcal plate. (C) Dorsal view showing antapical spine. (D) Antapical view. Scale bars: $5 \mu \mathrm{m}$ (Fig. 5A, C and D), $1 \mu \mathrm{m}$ (Fig. 5B).

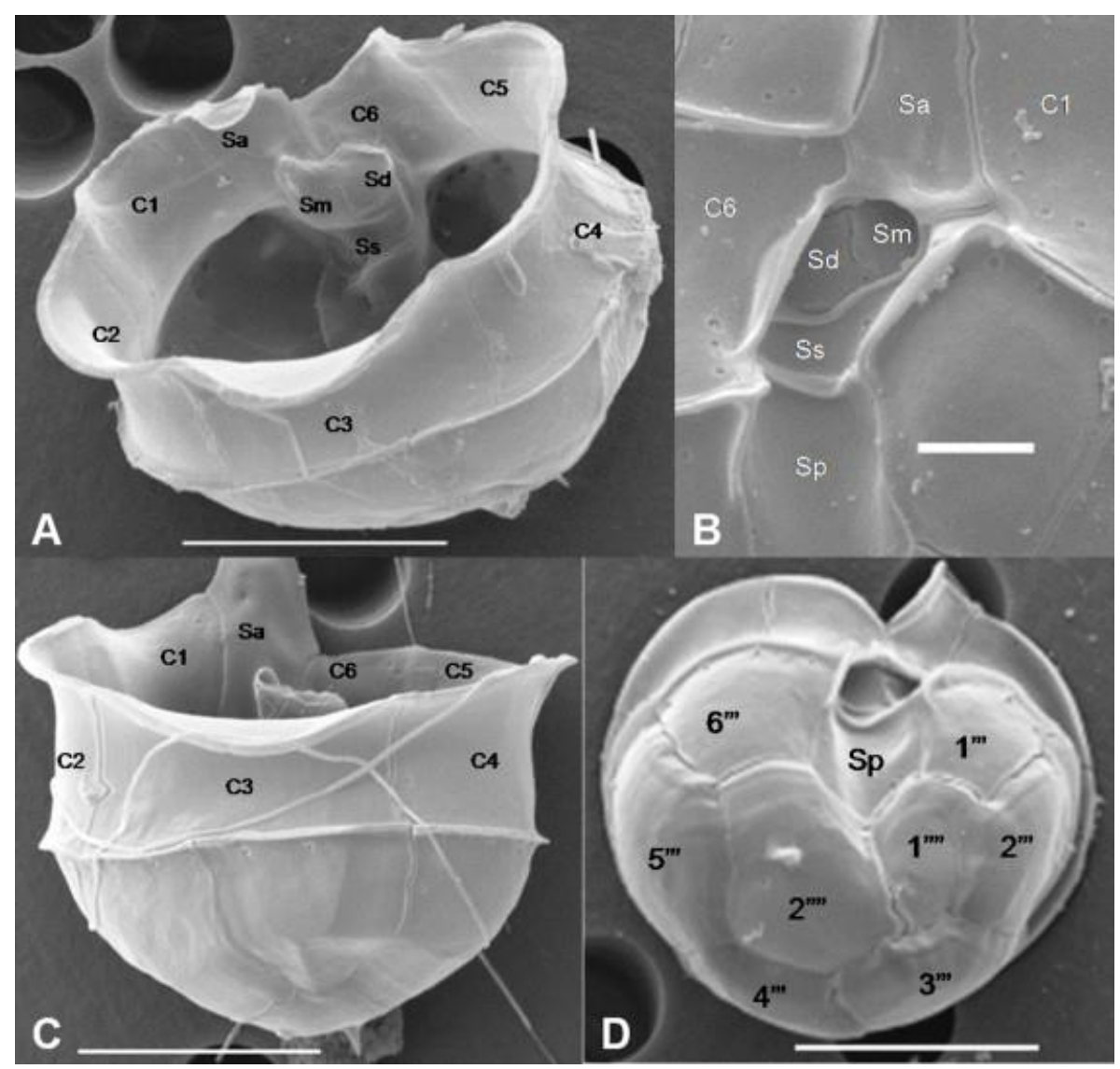


Figure 5. Maximum likelihood (ML) phylogenetic tree of the dinoflagellates inferred from the D1-D2 region of the 28S/large subunit (LSU) from the rDNA operon. The branch of the dinoflagellate Oxyrrhis marina, which was used as outgroup, is not shown proportionally. Bootstrap analysis was done with 100 replicates.

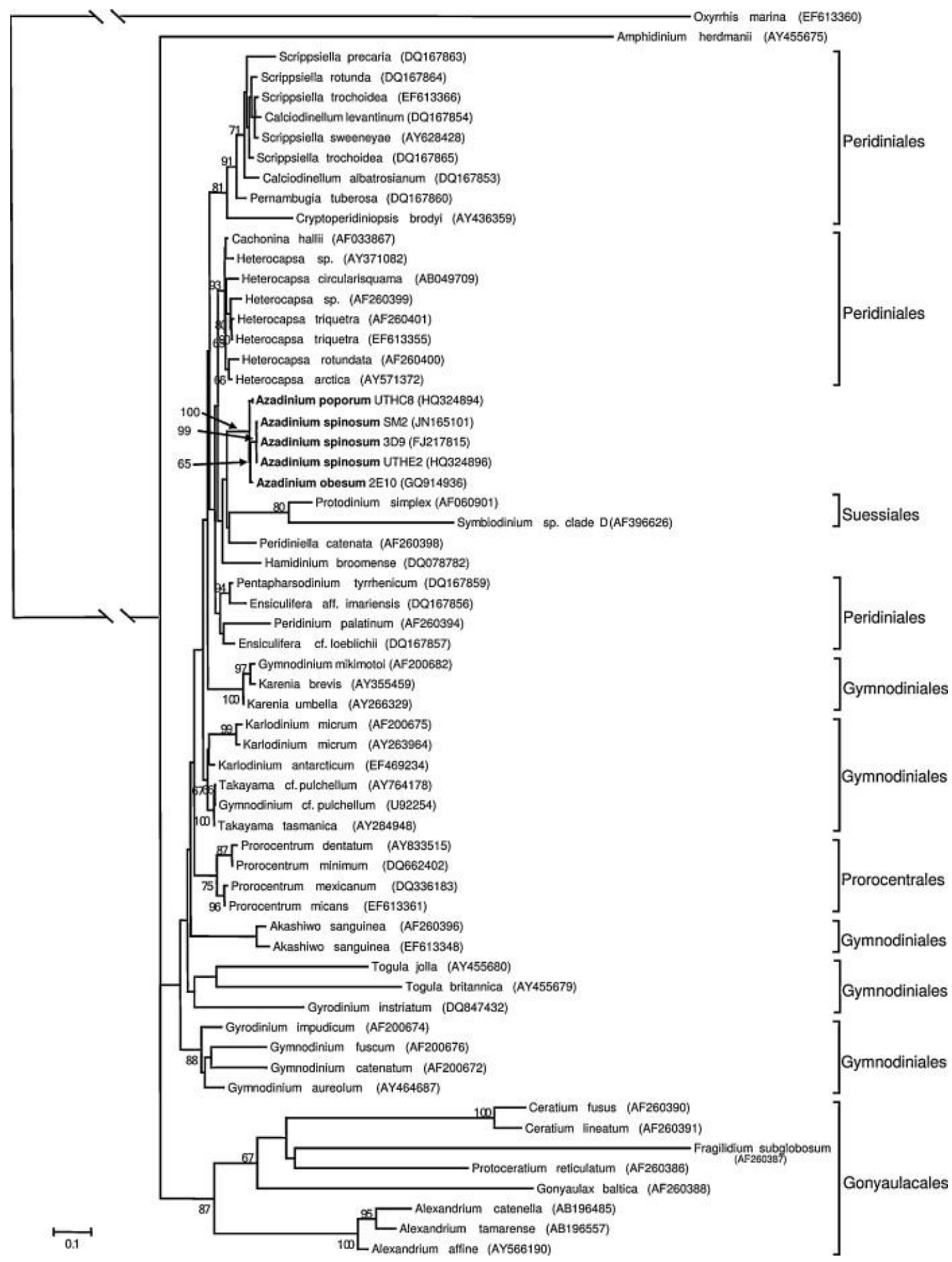


Figure 6. Cell densities of $A$. spinosum over $24 \mathrm{~h}$ in three treatments $(30,000,20,000,5000)$ and control.

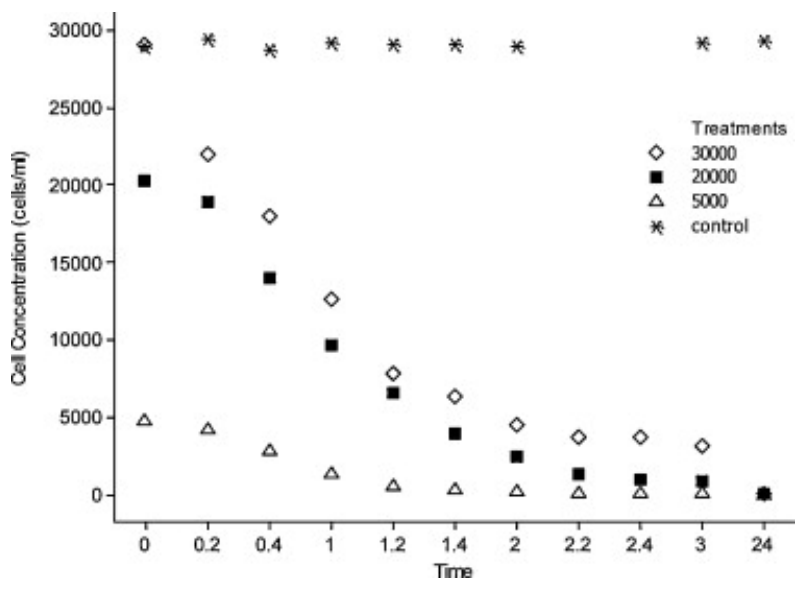

Figure 7. Azaspiracid concentrations $\left(\mathrm{mg} \mathrm{kg}^{-1}\right)$ found in mussels hepatopancreas $(n=9$ per treatment). $\mathrm{T} 1=30,000$ cells ml ${ }^{-1}, \mathrm{~T} 2=20,000$ cells ml${ }^{-1}, \mathrm{~T} 3=5000$ cells $\mathrm{ml}^{-1}$ and control.

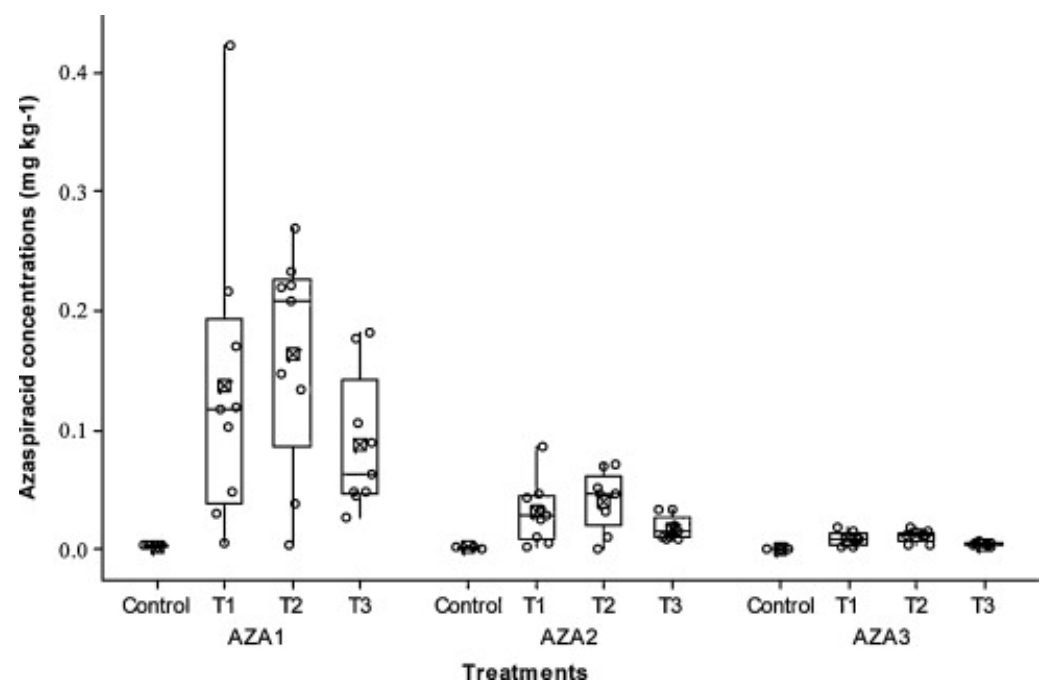


Appendix A. Supplementary data

Table S1. Azaspiracid toxins budget in the 20,000 treatment.

\begin{tabular}{|c|c|c|c|c|c|c|c|c|c|c|c|}
\hline \multirow{2}{*}{$\begin{array}{c}\text { Flasks } \\
\text { Replicates }\end{array}$} & \multirow{2}{*}{$\begin{array}{c}\text { Initial toxin } \\
\text { culture (ng) } \\
\text { AZA1 }\end{array}$} & \multicolumn{2}{|c|}{$\begin{array}{l}\text { Final toxin culture } \\
\text { (ng) }\end{array}$} & \multicolumn{3}{|c|}{ Tissue after 24 hrs (ng) } & \multicolumn{3}{|c|}{ Biodeposits (ng) } & \multirow{2}{*}{$\begin{array}{l}\text { Total (ng) } \\
\text { Total recovered }\end{array}$} & \multirow[t]{2}{*}{$\%$} \\
\hline & & AZA1 & AZA17 & AZA1 & AZA17 & AZA3 & AZA1 & AZA17 & AZA3 & & \\
\hline $20000 \mathrm{~F} 1$ & 1116.67 & 250.00 & 0.00 & 309.02 & 375.30 & 28.31 & 188.00 & 0.00 & 1.75 & 1152.38 & 103.2 \\
\hline 20000F2 & 1066.67 & 325.00 & 0.00 & 316.49 & 354.13 & 28.42 & 176.00 & 0.00 & 1.63 & 1201.67 & 112.7 \\
\hline 20000F3 & 1116.67 & 358.33 & 0.00 & 222.33 & 306.88 & 20.55 & 167.00 & 0.00 & 1.34 & 1076.44 & 96.4 \\
\hline \multirow[t]{2}{*}{ Mean } & 1100.00 & 311.11 & 0.00 & 282.61 & 345.44 & 25.76 & 177.00 & 0.00 & 1.57 & 1143.49 & 104.1 \\
\hline & & & & & & & \multicolumn{4}{|c|}{$\begin{array}{c}\% \text { toxins in suspended particulate matter } \\
\% \text { toxins in biodeposits }\end{array}$} & $\begin{array}{l}59.4 \\
28.3 \\
16.2\end{array}$ \\
\hline Replicates & AZA2 & AZA2 & AZA6 & AZA2 & AZA19 & AZA6 & AZA2 & AZA19 & AZA6 & Total recovered & \\
\hline $20000 \mathrm{~F} 1$ & 158.08 & 29.75 & 0.00 & 76.55 & 37.27 & 0.00 & 31.06 & 0.00 & 0.00 & 174.63 & 110.5 \\
\hline $20000 \mathrm{~F} 2$ & 139.46 & 38.96 & 0.00 & 70.21 & 31.40 & 0.00 & 28.59 & 0.00 & 0.00 & 169.16 & 121.3 \\
\hline 20000F3 & 129.01 & 37.25 & 0.00 & 56.95 & 21.94 & 0.00 & 33.46 & 0.00 & 0.00 & 149.59 & 116.0 \\
\hline \multirow[t]{2}{*}{ Mean } & 142.18 & 35.32 & 0.00 & 67.90 & 30.20 & 0.00 & 31.04 & 0.00 & 0.00 & 164.46 & 115.9 \\
\hline & & & & & & & \multicolumn{4}{|c|}{$\%$ toxins in mussel tissue } & 69.0 \\
\hline
\end{tabular}

Table S2. Azaspiracid toxins budget in the 5000 treatment.

\begin{tabular}{|c|c|c|c|c|c|c|c|c|c|c|c|}
\hline \multirow{2}{*}{$\begin{array}{c}\text { Flasks } \\
\text { Replicates }\end{array}$} & \multirow{2}{*}{$\begin{array}{l}\text { Initial toxin } \\
\text { culture (ng) } \\
\text { AZA1 }\end{array}$} & \multicolumn{2}{|c|}{$\begin{array}{l}\text { Final toxin culture } \\
\qquad(\mathrm{ng})\end{array}$} & \multicolumn{3}{|c|}{ Tissue after 24 hrs (ng) } & \multicolumn{3}{|c|}{ Biodeposits (ng) } & \multirow{2}{*}{$\begin{array}{c}\text { Total (ng) } \\
\text { Total recovered }\end{array}$} & \multirow[t]{2}{*}{$\%$} \\
\hline & & AZA1 & AZA17 & AZA1 & AZA17 & AZA3 & AZA1 & AZA17 & AZA3 & & \\
\hline $5000 \mathrm{~F} 1$ & 225.00 & 41.67 & 0.00 & 146.10 & 135.26 & 7.02 & 24.00 & 0.00 & 0.00 & 354.04 & 157.4 \\
\hline $5000 \mathrm{~F} 2$ & 216.67 & 33.33 & 0.00 & 97.05 & 109.07 & 6.88 & 24.00 & 0.00 & 0.00 & 270.33 & 124.8 \\
\hline $5000 \mathrm{~F} 3$ & 241.67 & 33.33 & 0.00 & 114.75 & 106.27 & 6.61 & 30.00 & 0.00 & 0.00 & 290.96 & 120.4 \\
\hline \multirow[t]{2}{*}{ Mean } & 227.78 & 36.11 & 0.00 & 119.30 & 116.87 & 6.84 & 26.00 & 0.00 & 0.00 & 305.11 & 134.2 \\
\hline & & & & & & & \multicolumn{4}{|c|}{$\begin{array}{c}\% \text { toxins in suspended particulate matter } \\
\% \text { toxins in biodeposits }\end{array}$} & $\begin{array}{c}106.7 \\
15.9 \\
11.4\end{array}$ \\
\hline Replicates & AZA2 & AZA2 & AZA6 & AZA2 & AZA19 & AZA6 & AZA2 & AZA19 & AZA6 & Total recovered & \\
\hline $5000 \mathrm{~F} 1$ & 25.21 & 9.77 & 0.00 & 28.37 & 12.52 & 0.00 & 5.60 & 0.00 & 0.00 & 56.25 & 223.1 \\
\hline $5000 \mathrm{~F} 2$ & 33.99 & 0.00 & 0.00 & 20.70 & 10.74 & 0.00 & 5.61 & 0.00 & 0.00 & 37.05 & 109.0 \\
\hline $5000 \mathrm{~F} 3$ & 25.20 & 0.00 & 0.00 & 23.42 & 11.90 & 0.00 & 6.56 & 0.00 & 0.00 & 41.88 & 166.2 \\
\hline \multirow[t]{2}{*}{ Mean } & 28.13 & 3.26 & 0.00 & 24.16 & 11.72 & 0.00 & 5.92 & 0.00 & 0.00 & 45.06 & 166.1 \\
\hline & & & & & & & \multicolumn{4}{|c|}{$\begin{array}{c}\% \text { toxins in suspended particulate matter } \\
\% \text { toxins in biodeposits }\end{array}$} & $\begin{array}{c}127.6 \\
11.6 \\
21.0\end{array}$ \\
\hline
\end{tabular}


Supplementary Figure S1. LC-MS/MS chromatogram (multi reaction monitoring (MRM) mode) of Azadinium spinosum SM2 isolate showing ion traces for AZA1, -2 and -3 .

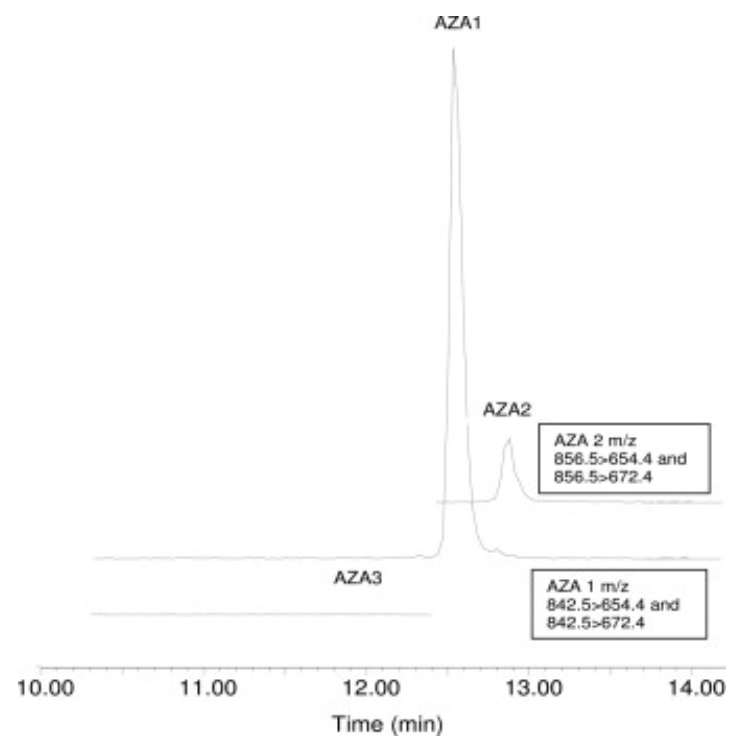

Supplementary Figure S2.: Azaspiracid concentration $\left(\mathrm{mg} \mathrm{kg}^{-1}\right)$ found in the mussel remainder tissue $\left(n=9\right.$ per treatment). T1 $=30,000$ cells mll ${ }^{-1}, \quad \mathrm{~T} 2=20,000$ cells ml $^{-1}$, $\mathrm{T} 3=5000$ cells ml${ }^{-1}$ and control. Please note that most AZA concentrations found in the reminder tissue were below the formal limit of quantification for the instrument.

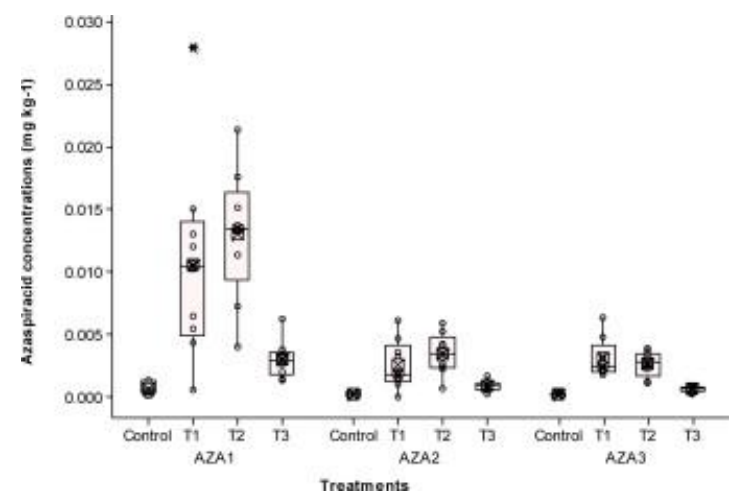

Supplementary Figure S3. AZA analogues found in mussel HP in treatment 30,000 cells ml $^{-1}$ after $24 \mathrm{~h}$.

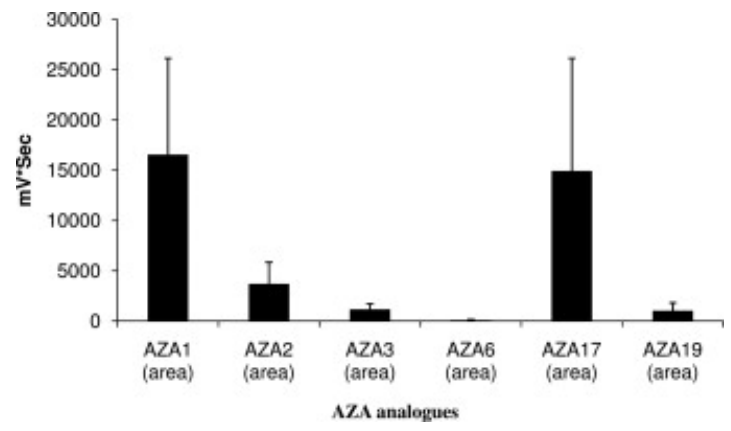


Supplementary Figure S4. AZA analogues found in mussel remainder tissues in treatment 30,000 cells $\mathrm{ml}^{-1}$ after $24 \mathrm{~h}(n=9)$.

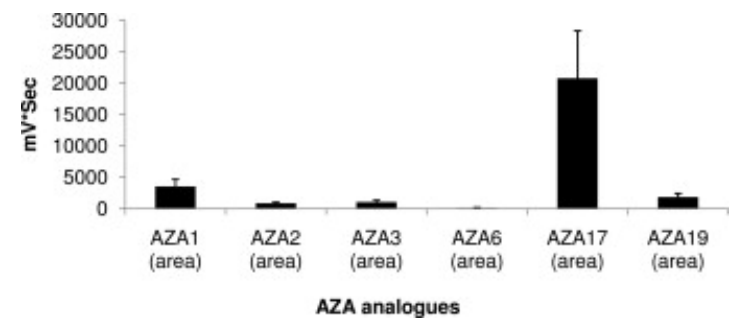

Supplementary Figure S5. Ratio of AZA 17/AZA 1 per treatment in mussel hepatopancreas after $24 \mathrm{~h}$.

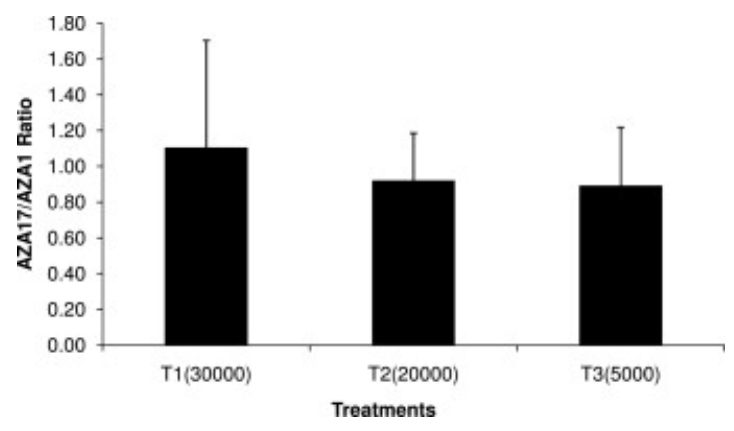

Supplementary Figure S6. Ratio of AZA 17/AZA 1 per treatment in mussel remainder tissues after $24 \mathrm{~h}$.

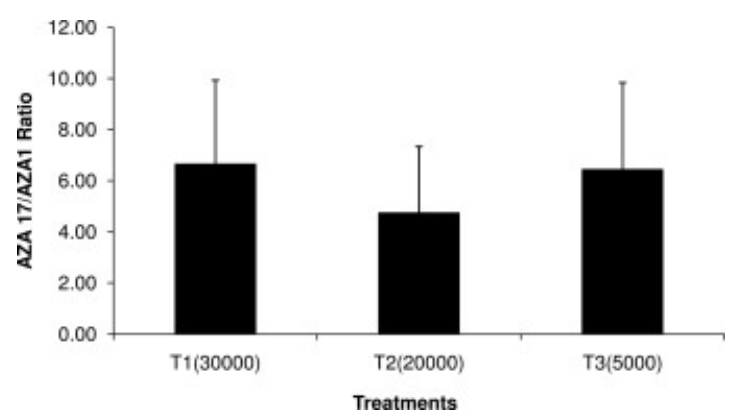

